\title{
Directed Therapies in Anaplastic Lymphoma Kinase-rearranged Non-small Cell Lung Cancer
}

\author{
RALPH L. MILLETT, JACOB M. ELKON and IMAD A. TABBARA \\ GW Cancer Center \& Department of Internal Medicine, \\ George Washington University School of Medicine, Washington, DC, U.S.A.
}

\begin{abstract}
Anaplastic lymphoma kinase (ALK) rearrangements were first implicated as driving mutations in non-small cell lung cancer in 2007. Since then, a number of novel, small-molecule inhibitors directed against the ALK receptor have demonstrated superiority over standard chemotherapies in the treatment of ALK rearrangement-positive lung cancer. Of considerable importance when considering such therapies is the ability of each to overcome mutations conferring acquired resistance, as well as penetrate the central nervous system (CNS), the most common site of metastasis and traditionally the most difficult to breach. Herein is a review of the efficacy, indications, and degree of CNS penetration for the ALK-targeting agents crizotinib, ceretinib, alectinib, brigatinib, and lorlatinib, as well as a summary of ongoing clinical trials comparing these drugs.
\end{abstract}

Lung cancer represents the leading cause of cancer-related mortality in the USA and worldwide $(1,2)$. About $80-85 \%$ of all lung cancer cases are classified as non-small cell lung cancer (NSCLC), a group of disparate diseases that are relatively insensitive to standard chemotherapeutic agents (2, $3)$. Historically, therapeutic approaches have, out of necessity, consisted of some variant of platinum-based double-agent treatment, associated with median survival times of less than 1 year following diagnosis $(2,4)$. However, with advances in molecular studies, a number of new subtypes of NSCLC have been identified and stratified

This article is freely accessible online.

Correspondence to: Imad A. Tabbara, MD, Professor of Medicine, Director Thoracic Oncology Program, GW Cancer Center, 2150 Pennsylvania Avenue, NW, Suite 1-200, Washington, DC 20037. U.S.A. Tel: +1 2027412478, Fax: +1 2027412487, e-mail: itabbara@mfa.gwu.edu

Key Words: $A L K$ rearrangement, crizotinib, ceritinib, alectinib, brigatinib, lorlatinib, NSCLC, review. by oncogenic driver, rather than histology alone. This, in turn, has led to the rapid development of novel and highly effective therapies against these various subtypes. One such variant, anaplastic lymphoma kinase $(A L K)$ rearrangementpositive lung cancer, has experienced a particularly rapid evolution in treatment approach and outcome since 2011.

\section{Biology}

The $A L K$ gene encodes a tyrosine kinase receptor from the insulin receptor superfamily on the p-arm of chromosome $2(2$, $5,6)$. In normal development, it is involved in the formation of neurons during embryogenesis before becoming thereafter dormant (6). ALK involvement was first implicated in lung cancer tumorigenesis in 2007 (4, 7). ALK rearrangementpositive lung cancer primarily arises from translocation of the $A L K$ gene and creation of subsequent fusion products. The most common of these is echinoderm microtubule-associated proteinlike 4 (EML4)-ALK, although a number of other fusion products have been described. Such types of cancer may also less frequently arise from gene amplification or random mutations leading to the activation of the $A L K$ gene itself $(2,8)$.

Regardless, these transformations represent between 3 and $7 \%$ of all NSCLC and result in constitutively active ALK signaling. A number of studies have demonstrated that $A L K$ rearrangement-positive carcinomas rely upon this continued ALK signaling for growth and survival, and so throttling of the oncogenic driver itself has proven an attractive point of attack for directed therapy $(9,10)$.

$A L K$ rearrangement-positive lung cancer has been reported in light-to never-smokers, younger patients (40- to 50-yearolds), and those with adenocarcinoma histology (11-14). Diagnosis is most typically made clinically via the Food and Drug Administration (FDA)-approved Vysis ALK BreakApart FISH Probe Kit or with the VENTATA anti-ALK (D5F3) immunohistochemical assay, although confirmatory polymerase chain reaction has also been used $(11,15,16)$. Since 2013, a number of national and international 
organizations have recommended routine ALK testing of all patients with NSCLC.

Central nervous system (CNS) disease. In considering ALK rearrangement-positive lung cancer, it is important to remember that in all NSCLC, metastasis to the CNS presents therapeutic challenge. CNS disease is the leading site of cancer progression and standard chemotherapy agents have poor CNS penetration due to the blood-brain barrier (BBB) and efflux drug pumps (16). Retrospective analysis indicates that between $20-30 \%$ of all $A L K$ rearrangement-positive NSCLC have CNS metastases at the time of diagnosis (compared to $10-20 \%$ in NSCLC overall). This number increases to between 45 and $75 \%$ in patients those with $A L K$ inhibitor, indicating that CNS disease represents a leading cause of mortality in $A L K$ rearrangement-positive lung cancer (4).

\section{ALK-Directed Therapy}

A: Crizotinib. Crizotinib (Xalkori, PF-02341066) is a smallmolecule inhibitor of the tyrosine kinases ALK, ROS1, and mesenchymal-epithelial transition factor (MET) and was the first direct ALK inhibitor tested in humans with $A L K$ rearrangement-positive lung cancer. In 2010, the phase I study PROFILE 1001 looked at crizotinib as a second-line treatment in patients previously treated with platinum-based chemotherapy (17). Compared to a $10 \%$ response rate and 2.5 months median progression-free survival (PFS) in patients with $A L K$ rearrangement-positive cancer treated with second-line chemotherapy, the crizotinib-treated arm demonstrated a significantly better overall response rate of $57 \%$ and a median PFS of 9.7 months. Shortly after this study, the FDA granted accelerated approval of crizotinib as a second-line therapy in the treatment of $A L K$ rearrangementpositive lung cancer (18).

Since that initial trial, crizotinib has continued to prove its merit over standard chemotherapeutic regimens. In PROFILE 1007, a phase III trial comparing second-line therapies in patients who had failed at least one previous platinum-based therapy, median PFS in the crizotinib arm was 7.7 months compared to 3.0 months in the second-line chemotherapy arm (either pemetrexed or docetaxel). Likewise, the overall response rate (ORR) in crizotinibtreated patients was significantly better at $65 \%$ compared to $20 \%$ (19).

In another phase III study (PROFILE 1014) comparing crizotinib to pemetrexed plus platinum chemotherapy in the treatment of naïve $A L K$ rearrangement-positive lung cancer, the drug's superiority over first-line regimens was established. Median PFS in the crizotinib arm was measured as 10.9 months compared to 7.0 months in the chemotherapy arm. Similarly, the ORR to crizotinib was $74 \%$ compared to
$45 \%$ for patients treated with pemetrexed plus platinum therapies (20). As a result of this study, crizotinib was approved as first-line agent by the FDA in $2013(18,21)$.

Typically dosed at $250 \mathrm{mg}$ twice daily, crizotinib is a relatively well-tolerated medication. In all of the crizotinib trials, quality of life measurements (cough, dyspnea, chest pain, fatigue, physical conditioning, etc.) were significantly better in the crizotinib-treated arms. The side-effect profile largely centers around grade 1 to 2 gastrointestinal manifestations, although grade 3 and 4 events have been reported in the form of elevated transaminase levels (Table I).

Acquired crizotinib resistance. Despite the initial successes demonstrated with crizotinib, time has shown that a majority of patients treated thus, will develop resistance to the drug and experience relapse within approximately 12 months (19, 22). Resistance to crizotinib can be separated into ALKdominant and ALK-independent processes. In the former, either new gain-of-function mutations or amplification of the $A L K$ gene serve to maintain constitutive ALK signaling even in the face of ongoing crizotinib therapy (17). Several such mutations have been described, the most common of which include the so-called gate-keeper mutation L1106M. These several mutations represent approximately one-third of resistant cases $(18,22)$. The latter, on the other hand, does not exactly represent insensitivity to crizotinib, but rather reactivation of bypass signaling pathways such as epidermal growth factor receptor (EGFR) or c-KIT which in large part obviate the tumor's dependence upon ALK activation for continued growth $(20,22)$. Clinically, it is clear that PFS with crizotinib therapy rarely extends beyond a year.

It should also be noted that crizotinib has a minimal impact on controlling metastatic CNS disease. Crizotinib is a known substrate of P-glycoprotein, a key efflux pump in the BBB (22). One study demonstrated extremely low concentrations of crizotinib in cerebrospinal fluid (23), indicating that the $\mathrm{BBB}$ may prevent it reaching therapeutic levels in lesions of the CNS. Interestingly, there is also one report indicating that isolated radiotherapy of CNS lesions in patients whose disease progresses on crizotinib led to favorable outcomes following resumption of crizotinib therapy, highlighting a potential method by which the efficacy of the agent may be prolonged (24).

B: Ceritinib. Ceritinib (Zykadia, LDK378), a secondgeneration small-molecule ATP-competitive tyrosine kinase inhibitor of the ALK receptor, is structurally different from and approximately 20-times more potent than crizotinib (25). Ceritinib has demonstrated promise in both crizotinib-treated and crizotinib-naive ALK positive lung cancer (26). For instance, a 2014 multicenter single-arm open-label clinical trial enrolled 163 patients with $A L K$ rearrangement-positive NSCLC that progressed despite crizotinib therapy. The 
Millett et al: Directed Therapies in $A L K$-rearranged NSCLC (Review)

Table I. Review of United States Food and Drug Agency-approved anaplastic lymphoma kinase (ALK) inhibitors.

\begin{tabular}{|c|c|c|c|c|c|}
\hline Agent (Ref) & FDA approval & Dosage & Molecular targets & AED > $>20 \%$ & Severe AED \\
\hline $\begin{array}{l}\text { Crizotinib } \\
(18,19,54)\end{array}$ & $\begin{array}{l}\text { Accelerated: First-line } \\
\text { (Aug 2011) } \\
\text { Regular: First-line } \\
\text { (Nov 2013) }\end{array}$ & $\begin{array}{l}250 \mathrm{mg} \text { per os } \\
\text { twice daily }\end{array}$ & $\begin{array}{l}\text { ALK, MET, } \\
\text { ROS1, RON }\end{array}$ & $\begin{array}{l}\text { Vision disorder, nausea, } \\
\text { vomiting, diarrhea, } \\
\text { edema, constipation }\end{array}$ & $\begin{array}{c}4 \% \text { (Increased ALT, } \\
\text { neutropenia); } 1.6 \% \\
\text { severe-to-fatal pneumonitis }\end{array}$ \\
\hline $\begin{array}{l}\text { Ceretinib } \\
(26,29)\end{array}$ & $\begin{array}{l}\text { Accelerated: Progression } \\
\text { or intolerance to } \\
\text { crizotinib (Apr 2014) } \\
\text { Regular: First-line } \\
\text { (May 2017) }\end{array}$ & $\begin{array}{l}750 \mathrm{mg} \text { per os } \\
\text { daily ( } 1 \mathrm{~h} \text { before } \\
\text { or } 2 \mathrm{~h} \text { after food })\end{array}$ & $A L K$ & $\begin{array}{c}\text { Diarrhea, nausea, vomiting, } \\
\text { fatigue, abdominal pain, } \\
\text { decreased appetite, cough }\end{array}$ & $\begin{array}{l}38 \% \text { (Increased creatinine, } \\
\text { increased amylase, } \\
\text { increased lipase); } 12 \% \\
\text { discontinuation, } 66 \% \\
\text { dose decrease }\end{array}$ \\
\hline $\begin{array}{l}\text { Alectinib } \\
(31,34,55)\end{array}$ & $\begin{array}{l}\text { Accelerated: Progression } \\
\text { or intolerance to } \\
\text { crizotinib (Dec 2015) } \\
\text { Regular: First-line } \\
\text { (Nov 2017) }\end{array}$ & $\begin{array}{c}600 \mathrm{mg} \text { per os } \\
\text { twice daily } \\
\text { with food }\end{array}$ & $A L K, R E T$ & $\begin{array}{c}\text { Fatigue, constipation, } \\
\text { edema, myalgia, anemia }\end{array}$ & $\begin{array}{c}\text { Renal impairment, } \\
\text { hyperbilirubinemia, } \\
\text { increased ALT, increased } \\
\text { ALT; } 11 \% \text { discontinuation, } \\
16 \% \text { dose decrease }\end{array}$ \\
\hline $\begin{array}{l}\text { Brigotinib } \\
(38,42)\end{array}$ & $\begin{array}{l}\text { Accelerated: Progression } \\
\text { or intolerance to } \\
\text { crizotinib (Apr 2017) }\end{array}$ & $\begin{array}{c}90 \text { mg PO daily } \times \\
7 \text { days, } 180 \mathrm{mg} \\
\text { PD daily after }\end{array}$ & $A L K, R O S 1$ & $\begin{array}{l}\text { Nausea, vomiting, diarrhea, } \\
\text { fatigue, cough, headache }\end{array}$ & $\begin{array}{c}\text { Pneumonia, ILD/pneumonitis; } \\
3.7 \% \text { fatal events; } \\
2.8 \%(90 \mathrm{mg}) / 8.2 \% \\
\text { (180 mg) dose decrease }\end{array}$ \\
\hline $\begin{array}{l}\text { Lorlatinib } \\
(46,56)\end{array}$ & $\begin{array}{l}\text { Breakthrough: } \\
\text { Progression after } \\
\text { any previous ALK } \\
\text { inhibitor therapy }\end{array}$ & $\begin{array}{l}\text { 10-200 mg once } \\
\text { daily, or } 35-100 \mathrm{mg} \\
\text { twice daily }\end{array}$ & $A L K, \operatorname{ROS} 1$ & $\begin{array}{c}\text { Peripheral edema, } \\
\text { hypercholesterolemia }\end{array}$ & $\begin{array}{c}\text { Grade } 3 \\
\text { hypercholesterolemia } 11 \%\end{array}$ \\
\hline
\end{tabular}

MET: Mesenchymal epithelial transition grown factor; RET: rearranged after transcription; RON: recepteur d'origine nantais.

results demonstrated an ORR of $54.6 \%$ with ceritinib as a second agent with a median PFS of 7.4 months (25) on top of the initial PFS achieved with crizotinib. This study ultimately garnered fast-track FDA approval of ceritinib as a second-line treatment.

In another phase I trial, ORR to ceritinib was $58 \%$, with minimal difference seen between crizotinib-treated and crizotinib-naïve cases (56 and $62 \%$, respectively). With a median PFS of 10.7 months in the crizotinib-naïve arm, there was evidence of near-equivalent efficacy between the two drugs as first-line agents. In 2017, a randomized open-label phase III trial (ASCEND 4) compared ceritinib to standard platinum-based chemotherapies. When compared to chemotherapy alone, ceritinib led to an actual doubling of median PFS (16.6 vs. 8.1 months) (27). The results of ASCEND 4 led to FDA approval of ceritinib as a first-line therapy in ALK rearrangement-positive lung cancer in May of the same year (28). In summary, ceritinib demonstrated not only improved PFS when used after crizotinib failure but also showed comparable efficacy as a first-line treatment.

The fact that ceritinib demonstrates effects on crizotinibresistant disease may be attributed to both its increased potency, as well as its action against certain acquired resistance mutations. By using cell lines derived from biopsies of crizotinib-resistant tumors, ceritinib was found to actively inhibit growth of at least four common resistance- associated mutations (L1196M, G1269A, S1206Y, and I1171T). However, a number of other mutations were found to confer resistance to ceritinib itself (namely G1202R and F1174C), indicating probable causes of disease progression despite ceritinib treatment (25).

Ceritinib is typically dosed at $750 \mathrm{mg}$ daily and the sideeffects consist primarily of gastrointestinal disturbances (Table I). Whereas little to no grade 3 to 4 diarrhea has been reported in crizotinib use, it does occur in approximately $7 \%$ of ceritinib-treated patients. There is also a significantly higher rate of grade 3 or 4 nausea (8). Finally, like crizotinib, ceritinib can lead to significant elevation of transaminases in some patients. All of the above symptoms appear to be reversible upon withdrawal of the drug (26).

C: Alectinib. Alectinib (Alcensa, CH5424602), a secondgeneration ALK-specific tyrosine kinase inhibitor that also demonstrates rearranged during transfection (RET) protooncogene activity, was recently shown to be a major actor in treating $A L K$ rearrangement-positive lung cancer. While initial phase II studies demonstrated consistent benefit in the use of alectinib in crizotinib-refractory disease $(29,30)$, its true promise lies in its potential as a first-line therapy. In the phase III trial J-ALEX, Japanese patients with ALK inhibitor-naïve $A L K$ rearrangement-positive cancer were given either alectinib or crizotinib as first-line therapy. At the end of the study 
(approximately 2 years), median PFS for the crizotinib-treated arm was 10.2 months, whereas median PFS had not yet been reached in patients treated with alectinib (31). Of note, some patients had been previously treated with standard chemotherapies, and at $300 \mathrm{mg}$ twice daily, the dose of alectinib in this trial was lower than in most subsequent studies.

The result of J-ALEX was mirrored in its global cousin ALEX, an international randomized open label study comparing alectinib to crizotinib in previously untreated advanced $A L K$ rearrangement-positive NSCLC. In this study, median PFS in the alectinib-treated arm was 25.7 months compared to 10.4 months for the crizotinib-treated patients. In addition, alectinib was associated with a $53 \%$ lower risk of progressive disease or death over the study time (16). While alectinib was dosed at the more typical $600 \mathrm{mg}$ twice daily in this study, its superiority to crizotinib was demonstrated in both cases. As a result, alectinib received FDA approved for first-line treatment of $A L K$ rearrangementpositive lung cancer in November of 2017 (32).

As for ceritinib, at least one retrospective study indicated that alectinib offers superior treatment (33). While direct comparisons between the ASCEND and ALEX trials cannot be drawn, general PFS trends between the various studies would seem to corroborate this. Future studies are required to more directly compare the two therapies.

CNS activity. While it is true that alectinib retains activity against common crizotinib-resistance mutations such as $A L K$ L1196M (25) and that, like ceritinib, it is a more potent inhibitor of the ALK receptor, its true advantage likely lies in the management of CNS disease. Unlike the other ALK inhibitors, alectinib does not appear to be a substrate of Pglycoprotein, one of the major efflux pumps located in the BBB (34). As a result, it likely has relatively higher activity in the CNS than other ALK inhibitors, something indirectly demonstrated by survival trends. In the ALEX trial, only $12 \%$ of patients in the alectinib-treated group developed CNS progression compared to $45 \%$ in the crizotinib-treated group. Furthermore, because CNS involvement was assessed in each patient prior to enrollment, it was possible to measure response to previously diagnosed CNS disease. In the alectinib-treated arm, $59 \%$ of such patients demonstrated a CNS response duration of greater than 12 months, while only $36 \%$ showed the same on crizotinib therapy (16).

Unfortunately, as with crizotinib and ceritinib, eventual resistance to alectinib is seemingly inevitable. The most common mutations identified include I1171N (unique to alectinib) as well as G1202R (which is shared with ceritinib) (35).

Standard alectinib therapy is $600 \mathrm{mg}$ orally twice daily. Side-effects (Table I) chiefly include anemia (20\%), myalgia $(16 \%)$, diarrhea $(45 \%)$, and vomiting $(38 \%)$, however, rates of adverse events leading to dose reduction/discontinuation appear to be lower than for therapy with crizotinib (16).
D: Brigatinib. Brigatinib (AP26113), another secondgeneration ALK inhibitor, differs from the others in its enhanced activity against tumors with a wide array of resistance-associated mutations (36). Twelve times more potent than crizotinib, preclinical study demonstrated a superior inhibitory profile for 17 separate secondary $A L K$ mutations including G1202R, one of the major causes of failure in both ceritinib and alectinib therapy (37). It is too early to discern what bearing such studies will have in actual practice, though initial trials appear to indicate favorable results.

In the prospective phase I/II trial ALTA, brigatinib was examined in patients with crizotinib-resistant cancer and demonstrated an ORR of 54\%. While this is roughly equivalent to similar studies looking at ceritinib and alectinib (50-56\%), median PFS of 12.9 months (and 15.6 months by the independent review board) was in fact significantly better with brigatinib when compared to 5.76.0 months for ceritinib and 8.1-8.9 months for alectinib $(25,29,35)$. This increase in PFS may correspond to expanded coverage of developed ALK resistance, although this cannot yet be conclusively determined. Importantly, the ORR of $67 \%$ and the median PFS of 15.6 months in patients with measurable brain metastases were even higher, indicating that like alectinib, brigatinib may have superior CNS activity (37). It received accelerated FDA approval in 2017 for $A L K$ rearrangement-positive lung cancer which demonstrates progression or intolerance to crizotinib (38).

Regarding first-line application, the ongoing ALTA-1L trial opened in April of 2016 and is a phase III study comparing brigatinib to crizotinib in ALK inhibitor-naïve ALK rearrangement-positive NSCLC (39).

There are currently two doses being used by ongoing studies: $90 \mathrm{mg}$ and $180 \mathrm{mg}$ with a 7-day lead-in of $90 \mathrm{mg}$. As with the other ALK inhibitors, gastrointestinal sideeffects including nausea, vomiting, and diarrhea are common (Table I). Unlike the others, however, is the rapid development of severe pulmonary toxicity upon initiation of the agent (pneumonia, interstitial lung disease, and pneumonitis). With a $3.7 \%$ rate of fatal events (largely pulmonary in etiology), it is currently recommended that patients be monitored for new or worsening pulmonary symptoms for the first week of treatment (38).

E: Lorlatinib. Lorlatinib (PF-06463922) is a thirdgeneration ALK inhibitor with wide activity against many known resistance-associated mutations, including G1202R $(40,41)$. Tailored to penetrate the CNS, animal studies have demonstrated approximately $30 \%$ CNS availability with superior efficacy in CNS lesions compared to alectinib (40). In humans, a recent study demonstrated potential use in both treatment-naïve and previously 
treated $A L K$ rearrangement-positive cancer. A 2017 phase II trial showed an ORR of $90 \%$ in treatment-naïve patients, $69 \%$ in crizotinib-treated patients, $33 \%$ in those treated with a non-crizotinib ALK inhibitor, and 39\% in those treated with two or three previous ALK inhibitors (42). Based on this study, lorlatinib was granted FDA breakthrough approval in 2017. The phase III trial CROWN comparing lorlatinib to crizotinib as first-line therapy is ongoing (43). Thus far, the drug appears generally well tolerated, with only a $3 \%$ rate of discontinuation due to drug-related adverse events and no associated deaths, however, it remains to be seen if this trend holds true in larger study populations.

\section{Prospective Inhibitors and Treatments}

While the current data for $A L K$ rearrangement-positive lung cancer have changed, there are more studies ongoing. Another ALK inhibitor X-396 (ensartinib) is being compared to crizotinib in metastatic $A L K$ rearrangement-positive lung cancer that has received no more than one chemotherapy and no prior ALK inhibitors (44). In addition, phase III comparison front-line studies between brigatinib and crizotinib (45), alectinib and crizotinib (46), and lorlatinib and crizotinib (47) are underway. In a second-line phase III, alectinib is being compared to standard chemotherapy (pemetrexed or docetaxel) for patients with $A L K$ rearrangement-positive NSCLC that have previously received platinum chemotherapy and crizotinib (48). In addition, adjuvant crizotinib is being studied after surgery for patients with stage IB-IIIA NSCLC (49). Finally, many interesting questions are being asked in phase II studies including second-line treatment after alectinib (50), combining ALK inhibitors with stereotactic radiation (51), with bevacizumab (52), and with programmed death ligand 1 inhibition (53). All the above questions will assist in further improving outcomes for these patients.

\section{Conclusion}

Efficacy of treatment for $A L K$ rearrangement-positive lung cancer has advanced considerably in the past decade. After the introduction of crizotinib, newer generations of ALKdirected treatments are proving superior as first-line therapies and important in treating diseases resistant to the first-generation drug. This improved efficacy is due to both activity against resistance-associated mutations, as well as CNS penetration and activity. With several of these agents receiving either accelerated or regular FDA approval within the past year, it will be important to follow survival trends in the general population and to continue to compare both first-and second-line agents against one another.

\section{References}

1 Key Statistics for Lung Cancer. (2018, January 4). From, https://www.cancer.org/cancer/non-small-cell-lung-cancer/ about/key-statistics.html

2 Pikor L, Ramnarine V, Lam S and Lam W: Genetic alterations defining NSCLC subtypes and their therapeutic implications. Lung Cancer 82(2): 179-189, 2013.

3 Awad M and Shaw A: ALK-inhibitors in non-small cell lung cancer: Crizotinib and beyond. Clin Adv Hematol Oncol 12(7): 429-439, 2014.

4 Soda M, Choi Y, Enomoto M, Takada S, Yamashita Y, Ishikawa S, Ishikawa S, Fujiwara S, Watanabe H, Kurashina K, Hatanaka H, Bando M, Ohno S, Ishikawa Y, Aburatani H, Niki T, Sohara $\mathrm{Y}$, Sugiyama $\mathrm{Y}$ and Mano H: Identification of the transforming EML4-AL fusion gene in non-small-cell lung cancer. Nature 448(7153): 561-566, 2007.

5 ALK receptor tyrosine kinase [Homo sapiens (human)]- GeneNCBI. (n.d.)., From: https://www.ncbi.nlm.nih.gov/gene? $\mathrm{Db}=$ gene \&Cmd=ShowDetailView\&TermToSearch $=238$

$6 \mathrm{Wu}$ J, Savooji, J and Liu D: Second-and third-generation ALK inhibitors for non-small cell lung cancer. J Hematol Oncol 9: 19, 2016.

7 Rikova K, Guo A, Zeng Q, Possemato A, Yu J, Haack H, Nardone J, Lee K, Reeves C, Li Y, Hu Y, Tan Z, Stokes M, Sullivan L, Mitchell J, Wetzel R, Macneill J, Ren J, Yuan J, Bakalarski C, Villen J, Kornhauser J, Smith B, Li D, Zhou X, Gygi S, Gu T, Polakiewicz R, Rush J and Comb M: Global survey of phosphotyrosine signaling identifies oncogenic kinases in lung cancer. Cell 131(6): 1190-1203, 2007.

8 Shaw A, Kim D, Mehra R, Tan D, Felip E, Chow L, Camidge D, Vansteenkiste J, Sharma S, De Pas T, Riely G, Solomon B, Wolf J, Thomas M, Schuler M, Liu G, Santoro A, Lau Y, Goldwasser M, Boral A and Engelman J: Ceritinib in ALK-Rearranged Non-SmallCell Lung Cancer. New Engl J Med 370(26): 2537-2539, 2014.

9 Soda M, Takada S, Takeuchi K, Choi Y, Enomoto M, Ueno T, Haruta H, Hamada T, Yamashita Y, Ishikawa Y, Sugiyama Y and Mano H: A mouse model for EML4-ALK-positive lung cancer. Proc Natl Acad Sci 105(50): 19893-19897, 2008.

10 Mcdermott U, Iafrate A, Gray N, Shioda T, Classon M, Maheswaran S, Zhou W, Choi H, Smith S, Dowell L, Ulkus L, Kuhlmann G, Greninger P, Christensen J, Haber D and Settleman J: Genomic alterations of anaplastic lymphoma kinase may sensitize tumors to anaplastic lymphoma kinase Inhibitors. Cancer Res 68(9): 3389-3395, 2008.

11 Takahashi T, Sonobe M, Kobayashi M, Yoshizawa A, Menju T, Nakayama E, Mino N, Iwakiri S, Sato K, Miyahara R, Okubo $\mathrm{K}$, Manabe $\mathrm{T}$ and Date $\mathrm{H}$ : Clinicopathologic features of nonsmall-cell lung cancer with EML4-ALK fusion gene. Ann Surg Oncol 17(3): 889-897, 2010.

12 Shaw A, Yeap B, Mino-Kenudson M, Digumarthy S, Costa D, Heist R, Solomon B, Stubbs H, Admane S, McDermott U, Settleman J, Kobayashi S, Mark E, Rodig S, Chirieac L, Kwak E, Lynch $\mathrm{T}$ and Iafrate A: Clinical features and outcome of patients with non-small-cell lung cancer who harbor EML4ALK. J Clin Oncol 27(26): 4247-4253, 2009.

13 Inamura K, Takeuchi K, Togashi Y, Nomura K, Ninomiya H, Okui M, Satoh Y, Okumura S, Nakagawa K, Soda M, Choi Y, Niki T, Mano H and Ishikawa Y: EML4-ALK fusion is linked to histological characteristics in a subset of lung cancers. J Thorac Oncol 3(1): 13-17, 2008. 
14 Wong D, Leung E, So K, Tam I, Sihoe A, Cheng L, Ho K, Au J, Chung L and Pik Wong M: The EML4-ALK fusion gene is involved in various histologic types of lung cancers from nonsmokers with wild-type EGFR and KRAS. Cancer 115(8): 1723-1733, 2009.

15 Shaw A and Engleman J: (2013). ALK in lung cancer: Past, present, and future. J Clin Oncol 31(8): 1105-1111, 2013.

16 Peters S, Camidge D, Shaw A, Gadgeel S, Ahn J, Kim D, Ou S, Pérol M, Dziadziuszko R, Rosell R, Zeaiter A, Mitry E, Golding $\mathrm{S}$, Balas B, Noe J, Morcos P and Mok T: Alectinib versus crizotinib in untreated ALK-positive non-small-cell lung cancer. New Engl J Med 377(9): 829-838, 2017.

17 Kwak E, Bang Y, Camidge R, Shaw AT, Solomon B, Maki R, Ou S, Dezube B, Jänne P, Costa D, Varella-Garcia M, Kim W, Lynch T, Fidias P, Stubbs H, Engelman J, Sequist L, Tan W, Gandhi L, Mino-Kenudson M, Wei G, Shreeve S, Ratain M, Settleman J, Christensen J, Haber D, Wilner K, Salgia R, Shapiro G, Clark J and Iafrate A: Anaplastic lymphoma kinase inhibition in non-small-cell lung cancer. New Engl J Med 363(18): 1693-1703, 2010.

18 FDA Approval for Crizotinib (2013). From: https:// www.cancer.gov/about-cancer/treatment/drugs/fda-crizotinib

19 Shaw A, Kim D, Nakagawa K, Seto T, Crinó L, Ahn M, De Pas T, Besse B, Solomon B, Blackhall F, Wu Y, Thomas M, O'Byrne K, Moro-Sibilot D, Camidge D, Mok T, Hirsh V, Riely G, Iyer S, Tassell V, Polli A, Wilner K and Jänne P: Crizotinib versus chemotherapy in advanced ALK-positive lung cancer. New Engl J Med 368(25): 2385-2394, 2013.

20 Solomon B, Mok T, Kim D, Wu Y, Nakagawa K, Mekhail T, Felip E, Cappuzzo F, Paolini J, Usari T, Iyer S, Reisman A, Wilner K, Tursi J and Blackhall F: First-line crizotinib versus chemotherapy in ALK-positive lung cancer. New Engl J Med 371(23): 2167-2177, 2014.

21 Chuang $\mathrm{J}$ and Neal $\mathrm{J}$ : Crizotinib as first line therapy for advanced ALK-positive non-small cell lung cancers. Transl Lung Cancer Res 4(5): 639-641, 2015.

22 Dagogo-Jack I and Shaw A: Crizotinib resistance: implications for therapeutic strategies. Ann Oncol 27(Suppl 3): iii42-iii50, 2016.

23 Toyokawa G, Seto T, Takenoyama M and Ichinose Y: Insights into brain metastasis in patients with ALK lung cancer: is the brain truly a sanctuary? Cancer Metast Rev 34(4): 797-805, 2015.

24 Takeda M, Okamoto I and Nakagawa K: Clinical impact of continued crizotinib administration after isolated central nervous system progression in patients with lung cancer positive for ALK rearrangement. J Thorac Oncol 8(5): 654-657, 2013.

25 Friboulet L, Li N, Katayama R, Lee C, Gainor J, Crystal A, Michellys P, Awad M, Yanagitani N, Kim S, Pferdekamper A, Li J, Kasibhatla S, Sun F, Sun X, Hua S, McNamara P, Mahmood S, Lockerman E, Fujita N, Nishio M, Harris J, Shaw A and Engelman J: The ALK inhibitor ceritinib overcomes crizotinib resistance in non-small cell lung cancer. Cancer Discov 4(6): 662-673, 2014.

26 Mologni L: Expanding the portfolio of anti-ALK weapons. Transl Lung Cancer Res 4(1): 5-7, 2015.

27 Soria J, Tan D, Chiari R, Wu Y, Paz-Ares L, Wolf J, Geater S, Orlov S, Cortinovis D, Yu C, Hochmair M, Cortot A, Tsai C, Moro-Sibilot D, Campelo R, McCulloch T, Sen P, Dugan M, Pantano S, Branle F, Massacesi C and De Castro G: First-line ceritinib versus platinum-based chemotherapy in advanced ALK- rearranged non-small-cell lung cancer (ASCEND-4): a randomised, open-label, phase 3 study. Lancet 389(10072): 917929, 2017.

28 Center for Drug Evaluation and Research. Approved DrugsFDA broadens ceritinib indication to previously untreated ALKpositive metastatic NSCLC. From: https://www.fda.gov/Drugs/ InformationOnDrugs/ApprovedDrugs/ucm560873.htm

29 Ou S, Ahn J, Petris L, Govindan R, Yang J, Hughes B, Lena H, Moro-Sibilot D, Bearz A, Ramirez S, Mekhail T, Spira A, Bordogna W, Balas B, Morcos P, Monnet A, Zeaiter A and Kim D: Alectinib in crizotinib-refractory ALK-rearranged non-smallcell lung cancer: a phase II global study. J Clin Oncol 34(7): 661-668, 2016.

30 Shaw A, Gandhi L, Gadgeel S, Riely G, Cetnar J, West H, Camidge D, Socinski M, Chiappori A, Mekhail T, Chao B, Borghaei H, Gold K, Zeaiter A, Bordogna W, Balas B, Puig O, Henschel V and Ou S: Alectinib in ALK-positive, crizotinibresistant, non-small-cell lung cancer: a single-group, multicenter, phase 2 trial. Lancet Oncol 17(2): 234-242, 2016.

31 Hida T, Nokihara H, Kondo M, Kim Y, Azuma K, Seto T, Takiguchi Y, Nishio M, Yoshioka H, Imamura F, Hotta K, Watanabe S, Goto K, Satouchi M, Kozuki T, Shukuya T, Nakagawa K, Mitsudomi T, Yamamoto N, Asakawa T, Asabe R, Tanaka $\mathrm{T}$ and Tamura $\mathrm{T}$ : Alectinib versus crizotinib in patients with ALK-positive non-small-cell lung cancer (J-ALEX): an openlabel, randomised phase 3 trial. Lancet 390(10089): 29-39, 2017.

32 Center for Drug Evaluation and Research. Alectinib approved for (ALK) positive metastatic non-small cell lung cancer (NSCLC). From: https://www.fda.gov/Drugs/Information OnDrugs/ApprovedDrugs/ucm584082.htm

33 Davies J, Martinec M, Martina R, Delmar P, Coudert M, Bordogna W, Golding S and Crane G: 98PRetrospective indirect comparison of alectinib phase II data $v s$. ceritinib real-world data in ALK NSCLC after progression on crizotinib. Ann Oncol 28(Suppl_2), 2017.https://doi.org/10.1093/annonc/mdx091.018

34 Kodama T, Hasegawa M, Takanashi K, Sakurai Y, Kondoh O and Sakamoto H: (2014). Antitumor activity of the selective ALK inhibitor alectinib in models of intracranial metastases. Cancer Chemoth Pharm 74(5): 1023-1028, 2014.

35 Zhang S, Anjum R, Squillace R, Nadworny S, Zhou T, Keats J, Ning Y, Wardwell S, Miller D, Song Y, Eichinger L, Moran L, Huang W, Liu S, Zou D, Wang Y, Mohemmad Q, Jang H, Ye E, Narasimhan N, Wang F, Miret J, Zhu X, Clackson T, Dalgarno $\mathrm{D}$, Shakespeare $\mathrm{W}$ and Rivera V: The potent ALK inhibitor brigatinib (AP26113) overcomes mechanisms of resistance to first-and second-generation ALK inhibitors in preclinical models. Clin Cancer Res 22(22): 5527-5538, 2016.

36 Kim D, Tiseo M, Ahn M, Reckamp K, Hansen K, Kim S, Huber R, West H, Groen H, Hochmair M, Leighl N, Gettinger S, Langer C, Paz-Ares Rodríguez L, Smit E, Kim E, Reichmann W, Haluska F, Kerstein D and Camidge D: Brigatinib in patients with crizotinib-refractory anaplastic lymphoma kinase-positive non-small-cell lung cancer: A randomized, multicenter phase II trial. J Clin Oncol 35(22): 2490-2498, 2017.

37 Gettinger S, Kim D, Tiseo M, Langer C, Ahn M, Shaw A, Huber R, Hochmair M, Kim S, Bazhenova L, Gold K, Ou S, West H, Reichmann W, Haney J, Clackson T, Haluska F, Kerstein D and Camidge D: OA08.06 brigatinib activity in patients with ALK NSCLC and intracranial CNS metastases in two clinical trials. J Thorac Oncol 12(1): S273-S274, 2017. 
38 Center for Drug Evaluation and Research. Approved DrugsBrigatinib. From: https://www.fda.gov/Drugs/InformationOn Drugs/ApprovedDrugs/ucm555841.htm

39 ClinicalTrials.gov. ALTA-1L Study: A Phase 3 study of brigatinib versus crizotinib in ALK-positive advanced non-small cell lung cancer patients (ALTA-1L) (April 30, 2016). From: https://clinicaltrials.gov/show/NCT02737501?link_type=CLINT RIALGOV\&access_num $=$ NCT02737501

40 Zou H, Friboulet L, Kodack D, Engstrom L, Li Q, West M, Tang R, Wang H, Tsaparikos K, Wang J, Timofeevski S, Katayama R, Dinh D, Lam H, Lam J, Yamazaki S, Hu W, Patel B, Bezwada D, Frias R, Lifshits E, Mahmood S, Gainor J, Affolter T, Lappin P, Gukasyan H, Lee N, Deng S, Jain R, Johnson T, Shaw A, Fantin V and Smeal T: PF-06463922, an ALK/ROS1 inhibitor, overcomes resistance to first and second generation ALK inhibitors in preclinical models. Cancer Cell 28(1): 70-81, 2015.

41 Shaw A, Friboulet L, Leshchiner I, Gainor J, Bergqvist S, Brooun A and Engelman J: Resensitization to crizotinib by the lorlatinib ALK resistance mutation L1198F. New Eng1 J Med 374(1): 54-61, 2016.

42 Solomon B, Shaw A, Ignatius Ou S, Besse B, Felip E, Bauer T, Soo R, Bearz A, Lin C, Clancy J, Abbattista A, Thurm H, Peltz G, Masters E, Martini J, James L and Seto T: OA 05.06 phase 2 study of lorlatinib in patients with advanced ALK rearrangement-positive/ROS1+ non-small-cell lung cancer. Oral abstract presented at WCLC2017: World Congress on Lung Cancer 2017: Tokyo, Japan, October 16, 2017.

43 Clinicaltrials.gov. A Study of lorlatinib versus crizotinib in first line treatment of patients with ALK-positive NSCLC (April 14, 2017). From: https://clinicaltrials.gov/ct2/show/NCT03052608

44 ClinicalTrials.gov. eXalt3: Study comparing X-396 (ensartinib) to crizotinib in ALK positive non-small cell lung cancer (NSCLC) patients (May 22, 2016). From: http://clinicaltrials.gov/ct2/ show/NCT02767804 (accessed 2018 Jan 18)

45 ClinicalTrials.gov. ALTA-1L study: A phase 3 Study of brigatinib versus crizotinib in ALK-positive advanced non-small cell lung cancer patients (ALTA-1L) (September 16, 2016).

46 ClinicalTrials.gov. A study comparing alectinib with crizotinib in treatment-naive anaplastic lymphoma kinase-positive advanced non-small cell lung cancer participants (ALEX) (November 28, 2017). From: http://clinicaltrials.gov/ct2/show/ NCT02075840 (accessed 2018 Jan 18)

47 ClinicalTrials .gov. A Study of lorlatinib versus crizotinib in first line treatment of patients with ALK-positive NSCLC (January 17, 2018). From: http://clinicaltrials.gov/ct2/show/ NCT030 52608 (accessed 2018 Jan 18)
48 ClinicalTrials.gov. Alectinib versus pemetrexed or docetaxel in anaplastic lymphoma kinase (ALK)-positive advanced non-small cell lung cancer (NSCLC) participants previously treated with platinum-based chemotherapy and crizotinib (December 14, 2017).

49 ClinicalTrials gov. Crizotinib in treating patients with stage IBIIIA non-small cell lung cancer that has been removed by surgery and ALK fusion mutations (an ALCHEMIST treatment trial) (December 11, 2017). From: http://clinicaltrials.gov/ ct2/show/NCT02201992 (accessed 2018 Jan 18)

50 ClinicalTrials.gov. LDK378 in patients with ALK positive NSCLC previously treated with alectinib. (November 6, 2017). From: http://clinicaltrials.gov/ct2/show/NCT02450903 (accessed 2018 Jan 18).

51 ClinicalTrials.gov. Ceritinib in combination with stereotactic ablative radiation metastatic lung adenocarcinoma (June 1, 2016). From: http://clinicaltrials.gov/ct2/show/NCT02513667 (accessed 2018 Jan 18).

52 ClinicalTrials.gov. Phase I/II trial of alectinib and bevacizumab in patients with advanced, anaplastic lymphoma kinase (ALK)positive, non-small cell lung Cancer (April 14, 2017).

53 ClinicalTrials.gov. A study of ALK inhibitor, ensartinib, and AntiPD-L1, durvalumab, in subjects with ALK-rearranged non-small cell lung cancer (August 29, 2017). From: http://clinicaltrials.gov/ ct2/show/NCT02898116 (accessed 2018 Jan 18).

54 Yasuda H, Figueiredo-Pontes L, Kobayashi S and Costa D: Preclinical rationale for use of the clinically available multitargeted tyrosine kinase inhibitor crizotinib in ROS1translocated lung cancer. J Thorac Oncol 7(7): 1086-1090, 2012.

55 Kodama T, Tsukaguchi T, Satoh Y, Yoshida M, Watanabe Y, Kondoh $\mathrm{O}$ and Sakamoto $\mathrm{H}$ : Alectinib shows potent antitumor activity against RET-rearranged non-small cell lung cancer. Mol Cancer Ther 13(12): 2910-2918, 2014.

56 Felip E, Bauer T, Solomon B, Besse B, James L, Clancy J, Klamerus K, Martini J, Abbattista A and Shaw A: MA07.11 Safety and efficacy of lorlatinib (PF-06463922) in patients with advanced ALK or ROS1 non-small-cell lung cancer (NSCLC). J Thorac Oncol 12(1): S383-S384, 2017.
Received June 17, 2018

Revised July 18, 2018

Accepted July 26, 2018 